УДК 372.853

DOI:

Олена Жабко, викладач фізики і астрономії, ВСП "Мукачівський фаховий коледж Національного університету біоресурсів і природокористування Украӥни”

\title{
ЕЛЕКТРОННИЙ ПОСІБНИК ЯК ЗАСІБ РЕАЛІЗАЦІЇ ОСВІТНІХ ЗАВДАНЬ У ПРОЦЕСІ ВИВЧЕННЯ ФІЗИКИ В КОЛЕДЖІ
}

У статті здійснено обгрунтування особливостей розробки і застосування електронного посібника як засобу реалізації освітніх завдань у проиесі вивчення фізики в коледжі. Проаналізовано підходи до розробки електронного посібника як навчальної програмної системи комплексного призначення, щзо забезпечує безперервність і повноту дидактичного циклу процесу навчання. Наголошено на иілях використання електронного посібника в освітньому процесі (можливість опанування навчального матеріалу незалежно від тимчасових рамок, підвищення об' єктивності оцінювання знань здобувачів освіти, можливість вивчення навчального матеріалу за допомогою проекиійної апаратури, постійного оновлення й актуалізацї навчального матеріалу, підвищення рівня самоконтролю).

Ключові слова: електронний посібник; формування компетентностей; здобувач освіти.

Jim. 11.

Olena Zhabko, Lecturer of Physics and Astronomy, Detachabloed Stractural Subdivision "Mukachevo Professional College of National University of Life and Environmental Sciences of Ukraine"

\section{ELECTRONIC MANUALAS A MEANS OF IMPLEMENTATION OF EDUCATIONAL TASKS IN THE PROCESS OF STUDYING PHYSICS IN COLLEGE}

The article substantiates the peculiarities of the development and application of the electronic textbook as means of implementation of educational tasks in the process of studying physics in college. The approaches to the development of an electronic textbook as a training software system for complex purposes, which ensures the continuity and completeness of the didactic cycle of the learning process, are analyzed. An emphasis is placed on the use of electronic textbooks in the educational process (the possibility of studying educational material regardless of time frame, increasing the objectivity of assessing the knowledge of students, the possibility of studying educational material using projection equipment, constant updating and updating of educational material, increasing objectivity, increasing the level of self-control). The peculiarities of the application of the electronic manual are defined, which consist in providing the opportunity to perform laboratory experiments, visit virtual museums, study and create virtual models, get quick access to any reference information, exercise self-control, observe processes and phenomena that, in principle, cannot be observed in real time: macro- and micro-world, dangerous and destructive processes, very fast and very slow processes. The conditions of using the electronic textbook at different stages of the training session are substantiated. It is emphasized that the introduction of electronic textbooks in the educational process revives the perception of students, arouses interest for learning, develops creative and cognitive abilities, is aimed at the formation of information competencies (awareness of the need for information, identifying ways to fill gaps in information, designing strategies for finding, identifying and gaining access to information, comparison and evaluation, organization, application, transmission of information, synthesis and creation of new information). It is concluded that the electronic textbook provides the implementation of educational tasks in the study of physics in college. The main advantages of using an electronic textbook are freedom of access, visualization of educational material and the ability to present it in small blocks of information, which makes learning the subject more flexible, simplifies the search for relevant materials and promotes the formation of general cultural and professional competencies.

Keywords: an electronic manual; formation of competencies; an applicant.

П остановка проблеми. Нові інформаційні технології стали визначальним засобом XXI ст. Саме їх розвиток дає широку можливість для винаходу нових методів і методик в освіті. Зокрема, це стосується електронного навчання, побудованого на основі використання Інтернету, що дає змогу створювати онлайн курси, урізноманітнювати їх тематику, загальну спрямованість та різні способи реалізації. Електронне навчання сьогодні - це освітній процес, в якому використовуються інтерактивні електронні засоби доставки інформації: компактдиски; корпоративні мережі; Internet, електронні підручники і електронні посібники.

Аналіз останніх досліджень і публікацій. Застосування електронного навчання у 


\section{ЕЛЕКТРОННИЙ ПОСІБНИК ЯКЗАСІБ РЕАЛІЗАЦІЇ ОСВІТНІХЗАВДАНЬ У ПРОЦЕСІ ВИВЧЕННЯ ФІЗИКИ В КОЛЕДЖІ}

формуванні загальнокультурних і професійних компетенцій були предметом таких вітчизняних дослідників, як В. Биков [1], який наголошував на важливій ролі електронного навчання, Л. Дибкова [3], яка зосередила дослідницьку увагу на мобільному навчанні як технології навчання, що базується на інтенсивному застосуванні сучасних мобільних засобів і технологій. В. Федорчук [9], В. Шевченко [11] розглядали електронний підручник і електронний посібник як засіб інформатизації сучасної освіти та інновацій у керуванні пізнавальною діяльністю. У рамках впровадження Концепції Нової української школи проводиться експеримент всеукраїнського рівня за темою “Електронний підручник для загальної середньої освіти" [7].

Дослідники $[2 ; 4 ; 6 ; 8 ; 10]$ звертають увагу на те, що однією 3 переваг використання нових інформаційних технологій є методи пошукової та творчої діяльності, застосування електронних засобів навчання, що забезпечує умови залучення студентів до створення презентацій на задану тему, які використовуються для додаткового пояснення матеріалу, сприяє доступу студентів до електронних бібліотек. Такий підхід забезпечує зростання інтересу до предмету, розвитку творчих здібностей здобувачів освіти, формування у них загальнокультурних і професійних компетенцій.

Мета статті: обгрунтувати особливості застосування електронного посібника як засобу реалізації освітніх завдань в умовах коледжу.

Виклад основного матеріалу. Зазначимо, що випускник сучасного коледжу повинен володіти такими якостями особистості: самостійно мислити; самостійно здобувати знання і застосовувати їх на практиці; вміти працювати з інформацією (отримувати, обробляти, передавати, зберігати, знаходити тощо); бути товариським, набувати умінь працювати в групі; вміти творчо мислити і генерувати різні ідеї; орієнтуватися у навколишньому світі і змінюватися для адаптації в новому суспільстві; самостійно інтелектуально і морально зростати, підвищувати свій культурний рівень. Звідси випливає основний напрямок розвитку освіти як особистісно-орієнтованої.

Електронний посібник (ЕП) є літературою нового покоління, яка об'єднала в собі переваги традиційних підручників і можливості комп'ютерних технологій. Погоджуємося 3 Л. Зайнутдиновою, що “електронний посібник це навчальна програмна система комплексного призначення, яка забезпечує безперервність і повноту дидактичного циклу процесу навчання, що надає теоретичний матеріал та забезпечує тренувальну навчальну діяльність і контроль рівня; це імітаційне моделювання навчального курсу 3 комп'ютерною візуалізацією і сервісними функціями із забезпеченням інтерактивного зворотного зв'язку" $[6,51]$. Отже, основна відмінність у функціональних можливостях, наприклад, ЕП дає змогу за ключовими словами швидко знаходити потрібну інформацію в більш короткому текстовому викладі, але при цьому насиченості показу, демонстрації, моделюванні завдяки мультимедійним технологіям, можливості повторити будь-який фрагмент заняття незалежно від форми: відео, текст, картинка, схема тощо. А також з ії допомогою може швидко перевірити знання, як за окремим заняттям так і за будь-якою темою, що дає можливість коригувати освітній процес залежно від результатів тестування і створювати індивідуальні плани розвитку окремого здобувача освіти.

Будь-який електронний посібник $є$ сукупністю взаємопов'язаних навчальних об'єктів. Це: символьні об'єкти (знаки, символи, тексти, графіки і т.п.); образні об’єкти (фото, малюнки, об'єкти комп'ютерної графіки і т.п.); аудіоінформація (усні тексти, діалоги, аудіохроніка, музика, звуки природних процесів і тваринного світу тощо); відеооб'єктив (анімації, моделі, відеосюжети тощо); об'єкти “віртуальної реальності” (тренажери, інтерактивні моделі, конструктори) тощо [10].

Аналіз наукових досліджень засвідчує, що при побудові електронного посібника важливо враховувати таке:

1. Обміркувати концепцію курсу та сконструювати схему навчання: визначити структуру курсу, підібрати лекційний матеріал і визначити спосіб контролю отриманих знань, спроєктувати підготовку всіх ілюстративних і наочних матеріалів.

2. Розробляти дизайн електронного підручника.

3. Створювати словник термінів - глосарій.

4. Спрогнозувати елементи управління, реалізацію на кожній сторінці підручника всіх можливих підказок, стрілок та інших елементів навігації.

5. Врахувати такі апаратні й програмні можливості, як: наскільки потужними $є$ комп'ютери, які версії операційних систем, браузерів й інших прикладних програм тощо [10].

Розроблений нами навчальний електронний посібник “Фізика” (для студентів першого курсу аграрних навчальних закладів I-II рівнів акредитації [5]) спрямований на удосконалення освітнього процесу в умовах коледжу. Його окремі розробки можна використовувати незалежно один 


\section{ЕЛЕКТРОННИЙ ПОСІБНИК ЯК ЗАСІБ РЕАЛІЗАЦІїОСВІТНІХЗАВДАНЬ У ПРОЦЕСІ ВИВЧЕННЯ ФІЗИКИ В КОЛЕДЖІ}

від одного. Наприклад, деякі матеріали можна використовувати при поясненні нового матеріалу, a інші - для узагальнення і закріплення пройденого матеріалу. Абсолютно всі заняття можна використовувати для самостійної роботи після вивчення теми на уроці, завдання для закріплення матеріалу і тести для самоперевірки.

Для здобувача освіти електронний посібник дає змогу виконувати лабораторні експерименти, відвідувати віртуальні музеї, вивчати і створювати віртуальні моделі, отримувати швидкий доступ до будь-якої довідкової інформації, здійснювати самоконтроль, спостерігати процеси і явища, які в принципі неможливо спостерігати в реальному часі: макроі мікросвіту, небезпечні і руйнівні процеси, дуже швидкі й дуже повільні процеси.

Переваги електронного посібника:

1. Розміщення: теоретичного матеріалу для студентів: лекцій, електронних таблиць для розв'язання завдань, запитань і завдань для діагностування рівня знань з окремих тем тощо; віртуальної лабораторії для проведення експериментів і перевірки правильності виконання евристичних завдань; електронного журналу; відеотеки.

2. Діагностування рівня знань студентів.

3. Демонстрація фрагментів відеофільмів, фотографій, графіків, формул, анімації досліджуваних процесів і явищ, роботи технічних пристроїв і експериментальних установок, презентацій тощо.

4. Проведення інтерактивних лекцій.

5. Дистанційне консультування студентів.

6. Проведення опитувань.

7. Організація моніторингу використання ЕП 3 фізики (щоденна статистика відвідувань, переглядів окремих матеріалів, джерел інформації (комп'ютер або мобільний телефон), країнучасниць, місць проживання учасників тощо).

ЕП з фізики має певну наукову новизну, оскільки при розробці його структурно-функціональних характеристик, необхідних для організації навчально-пізнавальної діяльності студентів, враховувалися об'єктивні умови освітнього процесу, специфіка установ освіти: недостатня оснащеність кабінетів фізики сучасним обладнанням і високий рівень забезпеченості студентів комп'ютерною технікою й сучасними мобільними телефонами, підключеними до мережі Інтернет.

Представлений нами електронний продукт електронний посібник “Фізика” $є$ інтерактивним підручником з фізики для студентів першого курсу аграрних закладів освіти I-II рівнів акредитаціі
Мукачівського фахового коледжу Національного університету біоресурсів і природокористування України [5] - створює умови для підвищення рівня компетенцій з даної навчальної дисципліни, надає можливість студентам отримати в дистанційній формі консультацію, взяти участь в інтерактивному спілкуванні учасників освітнього процесу. Особливістю цього засобу навчання $є$ не інформація, а особистісна продуктивна діяльність студентів, пов'язана 3 вивченням нового матеріалу шляхом виконання особливого типу евристичних завдань 3 перетворення навчальної інформації.

Викладач має можливість застосовувати ЕП на різних етапах заняття.

1. На етапі актуалізації знань ЕП може застосовуватися для: проведення фронтального опитування або взаємоконтролю; рішення різнорівневих якісних, розрахункових, графічних завдань; фізичного диктанту, бліц-опитування; роботи з систематизуючими, узагальнювальними таблицями, логічними схемами.

2. При вивченні нового матеріалу слайди i натурний експеримент створюють єдине інтерактивне пізнавальне середовище, в якому викладач комплексом вміло підібраних питань і завдань збуджує і спрямовує думку студентів до нових теоретичних висновків. Далі в ході закріплення уточнює, коригує розуміння здобувачами освіти нового знання, формує початкові вміння. Значно зручніше демонструвати відеоматеріали. У будь-який момент можна зупинити кадр високої якості для замальовки або коментаря. Можна відключити звук і дати можливість проаналізувати ситуацію студенту, а потім, включивши звук, перевірити правильність відповіді. 3'явилася можливість здійснити віртуальний експеримент на комп'ютерній моделі при неможливості проведення реального експерименту (з огляду на його небезпеку, відсутності обладнання або специфіки умов). Можливий перегляд отриманих графіків і аналіз явищ, що спостерігаються. Окремою перевагою ЕП стосовно відтворення навчальної графіки є простота кольорового виокремлення необхідних елементів і можливість відтворення динаміки побудов. У ході закріплення нового матеріалу ЕП застосовується для вивчення алгоритму пошуку рішення поставленої проблеми, оцінювання альтернатив, виявлення наслідків та їх значимості в теopii.

3. Застосування ЕП як засобу контролю результатів навчання. Поряд 3 традиційним контролем, призначеним для оцінки кінцевих результатів навчання, комп'ютер, мобільний 


\section{ЕЛЕКТРОННИЙ ПОСІБНИК ЯК ЗАСІБ РЕАЛІЗАЦІЇ ОСВІТНІХЗАВДАНЬ У ПРОЦЕСІ ВИВЧЕННЯ ФІЗИКИ В КОЛЕДЖІ}

телефон допомагають організувати контроль самого процесу навчання, здійснити діагностику ходу матеріалу з метою корекції подальшого освітнього процесу.

4. Застосування ЕП як засобу проведення лабораторних робіт. За допомогою програм 3 фізики можна віртуально виконувати лабораторні роботи (наприклад, “Визначення довжини світлової хвилі за допомогою дифракційної решітки"). Робота виходить більш наочною, ефективною. Інтерактивні лабораторні роботи можна виконувати в кабінеті фізики як індивідуальну роботу або ж самостійну. Змінюючи кожному студенту параметри, можна диференціювати й індивідуалізувати завдання. У кабінеті фізики можна проаналізувати хід лабораторної роботи з комп'ютерної моделі перед виконанням роботи або після ії виконання слід провести комп’ютерне дослідження цієї ж залежності. Все це сприяє виробленню дослідницьких навичок, спонукає до творчого пошуку закономірностей.

5. Використання ЕП стало необхідністю при виконанні евристичних завдань, для інтерактивного спілкування, дистанційного консультування, проведення інтерактивних лекцій.

Таким чином, ЕП створює умови для розуміння матеріалу, а не простого заучування. Впровадження ЕП в освітній процес, урізноманітнює сприйняття здобувачів освіти, викликає інтерес до навчання, розвиває творчі й пізнавальні здібності, спрямовується на формування інформаційних компетенцій (усвідомлення потреби в інформації, виявлення способів заповнити прогалини в інформації, конструювання стратегій знаходження, виявлення і отримання доступу до інформації, порівняння і оцінка, організація, застосування, передача інформації, синтез і створення нової інформаціі), комунікативних компетенцій (вміння формулювати цілі власної діяльності та робити висновки за їі результатами, вміння самостійно оцінювати результати роботи), предметні компетенції (наприклад, знання властивостей напівпровідників, що дозволили створити компактні флеш-карти для зберігання великих об'ємів інформаціі).

Відзначимо, що у створенні ЕП брали активну участь самі здобувачі освіти - студенти Мукачівського фахового коледжу Національного університету біоресурсів і природокористування України спеціальностей “Правознавство”, “Облік і оподаткування”, “Фінанси, банківська справа та страхування", “Туризм”, “Теодезіятаземлевпорядкування”, "Агрономія: організація та ведення фермерського господарства. Виробництво і переробка продукціі рослинництва", “Ветеринарна медицина": вони працювали над створенням навчальних фільмів 3 предмету, готували тематичні презентації з фізики. Якісні роботи студентів розміщувалися на сторінках ЕП.

У процесі апробації ЕП з фізики з метою підвищення його ефективності нами проводився моніторинг відгуків здобувачів освіти коледжу, вивчення думок і побажань учасників студентської спільноти.

Наприклад, перегляд навчальних презентацій “Струм в напівпровідниках”, спрямованих на формування проектувальних та конструкторських компетенцій, створені здобувачами освіти першого курсу, за результатами нашого опитування, показав високу активність здобувачів освіти: середня кількість відвідувачів за останні 30 днів - 154 особи (орієнтовно 57,12 \% учасників студентської спільноти), 62, 86 \% здобувачів освіти переглядали матеріали ЕП з фізики 3 мобільного телефону, 39,14 \% - 3 комп'ютера. Дані дають підставу стверджувати, що ЕП - це альтернатива електронним планшетам та класичним підручникам.

Результати поточної і підсумкової атестації 3 фізики дають підставу оптимістичного висновку: у здобувачів освіти формується позитивна мотивація до самостійної освітньої діяльності. Навчальна діяльність здобувачів освіти і їі результати індивідуалізуються, стають наближеними до особистісних особливостей студентів, а процес засвоєння нових знань стає більш інтенсивним, варіативним, продуктивним $\mathrm{i}$ технологічним порівняно з традиційним.

Висновки та перспективи подальших досліджень. Таким чином, основними перевагами застосування ЕП 3 фізики в освітньому процесі коледжу є: свобода доступу - здобувач освіти має можливість доступу через Інтернет до електронних курсів з будь-якого місця, де $\epsilon$ вихід в глобальну інформаційну мережу; компетентна, якісна освіта, більш низькі ціни на доставку засобів навчання - в електронному навчанні процес доставки освіти включає в себе тільки обмін інформацією через Інтернет без витрат з боку здобувача освіти на придбання навчально-методичної літератури; можливість поділу змісту електронного курсу на невеликі блоки інформації, що дозволяє зробити вивчення предмета більш компактним і спрощує пошук потрібних матеріалів; гнучкість навчання тривалість і послідовність вивчення матеріалів здобувач освіти вибирає сам, повністю адаптуючи весь процес навчання під свої можливості і потреби; можливість визначати критерії оцінки 


\section{ЕЛЕКТРОННИЙ ПОСІБНИК ЯК ЗАСІБ РЕАЛІЗАЦІЇ ОСВІТНІХЗАВДАНЬ У ПРОЦЕСІ ВИВЧЕННЯ ФІЗИКИ В КОЛЕДЖІ}

знань - в електронному навчанні є можливість виставляти чіткі критерії, за якими оцінюються знання, отримані студентом в процесі навчання.

Перспективами подальших досліджень можуть бути проблеми формування професійних компетенцій на основі застосування електронних посібників та забезпечення розвитку дистанційної освіти у коледжах в умовах соціальної невизначеності.

\section{ЛІТЕРАТУРА}

1. Биков В. Ю. Мобільний простір і мобільно орієнтоване середовище інтернет-користувача: особливості модельного подання та освітнього застосування, Інформаційні технології в освіті, № 17, 2013. C. 9-37. URL: http://ite.kspu.edu/webfm_send/736.

2. Вембер В.П. Навчально-методичні вимоги до електронного підручника. Науковий часопис НПУ імені М.П. Драгоманова. Серія № 2. Комп'ютерноорієнтовані системи навчання: зб. наукових праць. Київ: НПУ ім. М.П.Драгоманова, 2006. № 4 (11). C. 50-56. URL: http://elibrary.kubg.edu.ua/id/eprint/6056/1/ V Vember NPU 2006 IS.pdf

3. Дибкова Людмила. Перспективи електронного навчання у 21 столітті за допомогою застосування мобільних девайсів. Молодь і ринок. № 9. (176), 2019. С. $50-54$.

4. Діденко О.В. Сучасні вимоги щодо розробки та впровадження електронних підручників у систему професійно-технічної освіти. Збірник наукових праць Національної академії Державної прикордонної служби України. Серія: Педагогічні та психологічні науки. 2013. № 4. C. 87-98. URL: http://nbuv.gov.ua/UJRN/ znpnapv_ppn $2013 \_4 \_12$

5. Жабко О.Г. Фізика: електронний посібник для студентів першого курсу аграрних навчальних закладів I-II рівнів акредитаціi. Мукачево, 2019.

6. Зайнутдинова Л. Х. Создание и применение электронных учебников: (на прим. общетехн. дисциплин): Монография. Астрахань:ЦНТЭП, 1999. 363 с

7. Про проведення експерименту Всеукраїнського рівня за темою “Електронний підручник для загальної середньої освіти" (E-book for secondary education (EBSE), серпень 2018 року - серпень 2021 року: Наказ Міністерства освіти і науки України від 31 серпня 2018 p. № 957. URL: https://mon.gov.ua/ua/npa/proprovedennyaeksperimentu-vseukrayinskogo-rivnya-za-temoyuserpen-2018-roku-serpen-2021-roku

8. Товканець Г. В. Горват С.В. Телекомунікаційний проект як освітня технологія. Освіта і формування конкурентоспроможності фахівців в умовах євроінтеграції: збірник тез доповідей Міжнародної науково-практичної конференції (26-27 жовтня 2017р.м.Мукачево). Мукачево: Вид-во МДУ, 2017.С. 95 -96 .

9. Федорчук В. Електронний підручник як засіб інформатизації сучасної освіти. Педагогічна освіта: теорія і практика. 2012. Вип. 12. С. 153-158. URL: http:// nbuv.gov.ua/UJRN/znppo $201212 \quad 29$

10. Фіголь Н. Структура електронного навчального видання. Вісник Книжкової палати. 2014. № 7. С. 29 31.

11. Шевченко В.Л. Основи дидактичного проектування комп'ютерно орієнтованих навчальних комплексів для дистанційної освіти : навчально-методичний посібник. Київ, 2008. 152 с

\section{REFERENCES}

1. Bykov, V. Yu (2013). Mobilnyi prostir i mobilno oriientovane seredovyshche internet-korystuvacha: osoblyvosti modelnoho podannia ta osvitnoho zastosuvannia [Mobile space and mobile-oriented Internet user environment: features of model presentation and educational application]. Information technology in education. No. 17. pp. 9-37. Available at: http:// ite.kspu.edu/webfm send/736 [in Ukrainian]

2. Vember, V.P. (2006). Navchalno-metodychni vymohy do elektronnoho pidruchnyka [Educational and methodical requirements for the electronic textbook]. Scientific journal of NPU named after M.P. Dragomanova. Series No. 2. Computer-based learning systems: Coll. scientific works. Kyiv. No. 4 (11). pp. 50-56. Available at: http:// elibrary.kubg.edu.ua/id// eprint/ 6056/1/ V_Vember_NPU_2006_IS.pdf[in Ukrainian].

3. Dybkova Liudmyla (2019). Perspektyvy elektronnoho navchannia u 21 stolitti za dopomohoiu zastosuvannia mobilnykh devaisiv [Prospects for e-learning in the $21 \mathrm{st}$ century through the use of mobile devices]. Youth and the market. No. 9. (176). pp. 50-54. [in Russian].

4. Didenko,O.V. (2013). Suchasni vymohy shchodo rozrobky ta vprovadzhennia elektronnykh pidruchnykiv u systemu profesiino-tekhnichnoi osvity [Modern requirements for the development and implementation of electronic textbooks in the system of vocational education]. Collection of scientific works of the National Academy of the State Border Guard Service of Ukraine. Series: Pedagogical and Psychological sciences. No. 4. pp. 87-98. Available at: http://nbuv.gov.ua/UJRN/ znpnapv ppn 2013412 [in Ukrainian].

5. Zhabko, O.H. (2019). Fizyka: elektronnyi posibnyk dlia studentiv pershoho kursu ahrarnykh navchalnykh zakladiv I-II rivniv akredytatsii [Physics: electronic manual for first-year students of agricultural educational institutions]. Mukachevo. [in Ukrainian].

6. Zajnutdinova, L. Kh. (1999). Sozdanie i primenenie elektronnykh uchebnikov: (na prim. obshhetekhn. discziplin) : Monografiya [Creation and use of electronic textbooks: (for a comment on general technical disciplines): Monograph]. Astrakhan, 363 p. [in Ukrainian].

7. Pro provedennia eksperymentu Vseukrainskoho rivnia za temoiu "Elektronnyi pidruchnyk dlia zahalnoi serednoi osvity" (2018). [On conducting an experiment of the All-Ukrainian level on the topic "Electronic textbook for general secondary education"](E-book for secondary education (EBSE), August 2018-August 2021: Order of the Ministry of Education and Science of Ukraine dated August 31, No. 957. Available at: https://mon.gov.ua/ua/ $\mathrm{npa} /$ proprovedennya-eksperimentu-vseukrayinskogorivnya-za-temoyu-elektronnijpidruchnik-dlya-zagalnoyiserednoyi-osviti-e-book-secondary-education-ebseserpen-2018-roku-serpen-2021-roku [in Ukrainian]. 


\section{ЗМІСТ ЕКОЛОГІЧНОЇ ОСВІТИ В ПРЕДМЕТАХ ІНТЕГРОВАНИХ КУРСІВ В СЕРЕДНІЙ ШКОЛ СЛОВАЧЧИНИ}

8. Tovkanets, H. V. \& Horvat, S.V. (2017). Telekomunikatsiinyi proekt yak osvitnia tekhnolohiia [Telecommunication project as educational technology]. Education and formation of competitiveness of specialists in the conditions of European integration: collection of abstracts of the International scientific-practical conference (October 26-27, 2017, Mukachevo). Mukachevo, pp. $95-96$ [in Ukrainian].

9. Fedorchuk, V. (2012). Elektronnyi pidruchnyk yak zasib informatyzatsii suchasnoi osvity [Electronic textbook as a means of informatization of modern education]. Pedagogical education: theory and practice. Vol. 12.pp. 153-158. Available at: http://nbuv.gov.ua/UJRN/znppo_2012_12_29. [in Ukrainian].

10. Fihol, N. (2014). Struktura elektronnoho navchalnoho vydannia [The structure of the electronic educational publication]. Bulletin of the Book Chamber. No. 7.pp. 29-31. [in Ukrainian].

11. Shevchenko, V. L. (2008). Osnovy dydaktychnoho proektuvannia kompiuterno oriientovanykh navchalnykh kompleksiv dlia dystantsiinoi osvity: navchalnometodychnyi posibnyk [Fundamentals of didactic design of computer-oriented educational complexes for distance education: a textbook]. Kyiv, 152 p. [in Ukrainian].

Стаття надійшла до редакції 10.11.2020

УДК 373:364

DOI:

Оксана Турок, вчитель біологї Рахівського закладу загальної середньої освіти I-III ступенів № 1, здобувач ступеня доктора філософії

\section{ЗМІСТ ЕКОЛОГІЧНОЇ ОСВІТИ В ПРЕДМЕТАХ ІНТЕГРОВАНИХ КУРСІВ В СЕРЕДНІЙ ШКОЛІ СЛОВАЧЧИНИ}

У статті розглянуто основні способи впровадження екологічної освіти як наскрізної теми в освітній процес середньої школи Словаччини. Визначено основні способи формування екологічної компетенції учня та виокремлено теми у змісті інтегрованих курсів, в яких екологічна освіта є наскрізною темою. Акцентовано увагу на злагодженій роботі формальної і неформальної екологічної освіти в середній школі Словацькоі Республіки. Доведено, що модулі навчальних курсів “Феномени світу” та інтегроване етичне виховання сприяють розвитку екологічної компетенції учня.

Ключові слова: екологічна освіта; наскрізна екологічна освіта; середня школа; освіта Словаччини; формування екологічної компетенції.

Лim. 8.

Oksana Turok, Teacher of Biology, Rakhiv Establishment of General Secondary Education of I-III degrees № 1, Applicant of the degree of Doctor of Philosophy

\section{THE SUBJECTS OF INTEGRATED COURSES IN SECONDARY SCHOOLS OF SLOVAKIA}

The article considers the main ways of introducing the cross-cutting theme of environmental education into the educational process of high school students in Slovakia. An environmental education of the younger generation is becoming increasingly important in the context of the intensifying environmental crisis and its consequences for the wellfare and well-being of everyone. The ways of the formation of the student's ecological competence during studying of various subjects have been defined. It has been emphasized that there is the need to include environmental topics in the study of subjects not only in the natural cycle such as Physics, Chemistry, and Biology. An accent has been placed on the positive experience of using the subjects of integrated courses in the educational process of secondary school in the Slovak Republic. The importance of coordinated work of formal and non-formal education has been shown. The documents influencing the formation of the educational process of the Slovak secondary school have been analyzed.

The expediency of introduction of new educational standards has been substantiated, which gives the chance to form ecological competence of the graduate of the second degree of high school of Slovakia (the 9th grade) through mastering of themes of integrated courses and subjects of the basic cycle. It has been established that integrated courses have been introduced into the educational process of secondary school in accordance with the updated educational programmes of the Slovak secondary school and world trends in the reform of the secondary education system. The general tendencies of the formation of ecological education of high school students have been singled out. It has been proved that the modules of the training courses "Phenomena of the World" and integrated aesthetic education contribute to the development of ecological competence of the student. The content of the integrated courses "Phenomena of the World" and integrated aesthetic education have been analyzed and revealed and it has been indicated in which specific topics the student's ecological competence has been formed. It has been 